\title{
Kritik Sosial dalam Novel Pasung Jiwa Karya Okky Madasari (Social Criticism in the Novel Pasung Jiwa by Okky Madasari)
}

\section{Lusy Novitasari ${ }^{\mathrm{a}, 1}$}

aSTKIP PGRI Ponorogo, Indonesia

${ }^{1}$ lucydheny77@gmail.com

\begin{tabular}{l} 
Article info \\
\hline Article history: \\
Received: $31-05-2020$ \\
Revised : 01-03-2021 \\
Accepted: 16-05-2021
\end{tabular}

Keywords Pasung Jiwa novel Okky Madasari social criticism in novel

A B S T R A C T

This study aims to describe and explain the social criticism contained in the novel Pasung Jiwa by Okky Madasari. The method used is the descriptive qualitative method. The data source of this research is the text of the novel Pasung Jiwa by Okky Madasari, first printed in 2013 and published by PT Gramedia Pustaka Utama Jakarta Publisher. This research is focused on problems related to social criticism. The data was obtained by using the document technique and analyzed in terms of content. The approach used in the sociology of literature. The research stages consist of data identification, data description, data analysis, and data interpretation. The results of the study indicate that this novel contains criticisms of parental/family confinement, abuse of transgender women, the miserable life of factory workers, the lives of commercial sex workers, those in power, and government arbitrariness, as well as the existence of laskar/religious defenders.

Penelitian ini bertujuan untuk mendeskripsikan dan menjelaskan kritik sosial yang terdapat dalam novel Pasung Jiwa karya Okky Madasari. Metode yang digunakan adalah metode deskriptif kualitatif. Sumber data penelitian ini adalah teks novel Pasung Jiwa karya Okky Madasari, cetakan pertama tahun 2013 dan diterbitkan oleh Penerbit PT Gramedia Pustaka Utama Jakarta. Penelitian ini difokuskan pada permasalahan yang berkaitan dengan kritik sosial. Data diperoleh dengan menggunakan teknik dokumen dan dianalisis dari segi isi. Pendekatan yang dipergunakan adalah sosiologi sastra. Tahapan penelitian terdiri atas: identifikasi data, deskripsi data, analisis data, dan interpretasi data. Hasil penelitian menunjukkan bahwa novel ini mengandung kritik terhadap: kungkungan orang tua/keluarga, kesewenangan kepada waria (transgender), kehidupan nestapa buruh pabrik, kehidupan pekerja seks komersial, pihak yang berkuasa dan kesewenangan pemerintah, serta adanya laskar/pasukan pembela agama.

Copyright $(\odot 2021$ Institut Agama Islam Negeri Syekh Nurjati Cirebon. All rights reserved.

\section{PENDAHULUAN}

Sastra merupakan karya kreatif imajinatif manusia dalam bidang seni dengan menggunakan media bahasa. Istilah sastra di dalam bahasa Indonesia berasal dari bahasa Sansekerta susastra yang memiliki makna yang indah (Brahmana, 2008). Sastra merupakan suatu kegiatan kreatif, sebuah karya dalam bidang seni. Pendapat lainnya menyatakan bahwa sastra adalah sebagai penciptaan yang bertumpu pada kreativitas, dan karya sastra bergulat dengan 
keindahan atau estetika (Sutejo \& Kasnadi, 2010). Sesuai dengan pernyataan mengenai sastra oleh beberapa ahli tersebut dapat dirumuskan bahwa dalam sastra terdapat sebuah dunia baru yang diciptakan oleh pengarang dan di dalamnya banyak terdapat pelik cerita kehidupan dari tokoh-tokoh imaji.

Sebagai sebuah hasil karya, sastra tidak hanya terbentuk dari unsur-unsur intrinsik yang mendukung ceritanya, karya sastra dalam bentuk novel, cerpen, puisi, dan naskah drama mengandung unsur-unsur sosiologis, psikologis, maupun antropologis karena karya sastra diciptakan oleh sastrawan yang jelas merupakan anggota masyarakat dan karya sastra dinikmati oleh masyarakat pula. Karya sastra merupakan persoalan warga masyarakat yang ditulis untuk kemudian dibaca oleh masyarakat pula (Wahyudi, 2013). Hal ini senada dengan ungkapan lain yang menjelaskan bahwa masyarakat sebagai sebuah subsistem kehidupan yang di dalamnya memiliki ciri unik, konflik, serta benturan yang kompleks antar individu merupakan hal menarik untuk ditulis pengarang (Sariban, 2015). Hal ini sejalan pula dengan ungkapan bahwa sastra merepresentasikan realitas secara akurat/valid (Artika, 2015).

Oleh sebab itu, karya sastra bisa dipandang sebagai cermin kehidupan masyarakat yang di dalamnya terdapat berbagai pelik masalah termasuk adanya budaya yang berkembang. Karya sastra bisa dibahas, dikaji atau diteliti melalui bermacam pendekatan yang sesuai dan adanya keterkaitan dengan segala hal yang menyangkut kehidupan manusia atau masyarakat (Sadewa, 2012). Karya sastra sebagai potret kehidupan masyarakat dapat dinikmati, dipahami, dan dimanfaatkan oleh masyarakat. Oleh karena itu, sastra sebagai karya yang menggunakan bahasa sebagai mediumnya menegaskan bahwa cerita atau hasil karya sastra tersebut memiliki fungsi sebagai pengendali sosial, atau dengan kata lain sebagai kritik sosial.

Karya sastra dalam aliran realisme dapat dikatakan sebagai bentuk peniruan dunia subjektif manusia dalam peristiwa yang spesifik dikehidupan sehari-hari. Karya sastra merupakan pencerminan dari dunia nyata atau pencerminan dari zamannya yang diolah oleh sastrawan melalui proses kreatif imajinatif hingga menjadi sebuah karya. Kehidupan pengarang dalam menciptakan karya sastra tentulah dilatarbelakangi dari keadaa sekelilingnya. Dengan kata lain, dunia realitas merupakan cerminan yang dapat dijadikan bahan karya sastra, kemudian diolah oleh sastrawan menjadi sebuah karya seni yang sesuai dengan apa yang dipikirkan, dikehendaki terkait dengan konflik, berbagai keunikan fenomena masyarakat dan berbagai hal menarik dari masyarakat itu sendiri. Pernyataan tersebut senada dengan pernyataan bahwa sastra menyajikan soal kehidupan, dan kehidupan itu sendiri sebagian besar merupakan kenyataan sosial dalam masyarakat, walaupun karya sastra itu sendiri juga dipandang suatu gejala social Wellek \& Warre, 2014).

Karya sastra lahir di tengah-tengah kehidupan masyarakat umumnya sebagai hasil dari imajinasi seorang pengarang serta refleksi terhadap gejala-gejala sosial di sekitarnya (Satrio, Doyin, \& Suseno, 2014). Ketika sastra dipandang sebagai sebuah cerminan dari kehidupan masyarakat, maka merupakan hal yang wajar jika sebuah teks sastra dikaji, dianalisis bahkan diteliti dengan menggunakan pendekatan sosiologi sastra. Sastrawan sebagai anggota masyarakat tidak dapat dipungkiri bahwa dalam sebuah proses penciptaan karya hingga lahirnya sebuah karya baik itu novel, cerpen, puisi, dan begitu juga naskah drama sangat dipengaruhi oleh berbagai keadaan sosial dan situasi masyarakat yang 
melingkupinya. Hal-hal yang melatarbelakangi dalam proses kreatif sastrawan itu bisa karena latar belakang agama, sosial, budaya, bahkan latar belakang atau cerita hidup dari sastrawan itu sendiri.

Melalui karya itulah seorang sastrawan berusaha berkomunikasi dengan masyarakat pada umumnya dan para pembaca atau penikmat sastra khususnya (Mulyaningsih, 2015). Tidak mengherankan apabila sebuah karya sastra syarat akan cerita kehidupan baik itu yang dianggap tabu atau hanya sebagai cerita biasabiasa saja. Oleh sebab itu, tidak bisa menutup fakta pula apabila sebuah karya sastra merupakan karya yang didalamnya terdapat kritik sosial yang ingin disampaikan pengarang dengan berlatar belakang permasalahan baik dalam sosial, politik, dan agama. Di samping itu, kritik sosial muncul karena adanya masalah sosial (Yulianto, 2017). Hal ini sejalan dengan pendapat bahwa karya sastra yang di dalamnya mengandung pesan mengenai kritik atau disebut dengan sastra kritik, lahir di tengah-tengah masyarakat jika terjadi hal-hal yang dirasa kurang benar dalam kehidupan baik sosial dan masyarakat (Nurgiyantoro, 2000). Kritik sosial yang terdapat dalam sebuah karya sastra baik berupa cerpen, novel, puisi bahkan juga karya berupa film dapat berupa hal yang menyindir atau sindiran dan tanggapan yang sengaja ditulis pengarang dan berusaha ditujukan pada masyarakat yang mengalami ketimpangan dan kecacatan dalam kehidupan sekitarnya (Melati, 2019).

Kata kritik sama dengan apresiasi atau catatan (Suhardi, 2020). Kritik sosial merupakan suatu bentuk kecaman terhadap berbagai ketimpangan dan bentuk ketidakadilan yang telah atau sedang terjadi dalam kehidupan bermasyarakat yang memiliki tujuan untuk mewujudkan keadilan sosial yang lebih manusiawi dengan citra yang tegas dan lebih jernih (Krisdayanti, Udu, \& Balawa, 2020). Sejalan dengan pendapat yang menyebutkan bahwa karya sastra juga mencerminkan kritik sosial dalam masyarakat yang bisa saja tersembunyi (Sugiwardana, 2014). Dengan demikian, kritik sosial merupakan tanggapan ataupun apresiasi seseorang terhadap perilaku sosial tokoh yang digambarkan sastrawan dalam cerita yang terkandung dalam karya sastra baik cerpen, novel, ataupun naskah drama.

Novel merupakan sejenis cerita fiksi yang muncul belakangan dibandingkan cerita pendek dan roman (Pratiwi, Harun, \& Herman, 2018). Sastra juga menawarkan dua hal utama, yaitu kesenangan dan pemahaman. Novel merupakan salah satu dari karya sastra yang sering dipilih untuk dianalisis karena memiliki banyak aspek-aspek di dalamnya termasuk kesenangan dan pemahaman. Novel merupakan karya kreatif imajinatif yang berusaha menceritakan sisi utuh terkait problematika kehidupan seorang tokoh atau beberapa orang tokoh (Kosasih, 2012). Lebih lanjut, pendapat lainnya mengemukakan pendapatnya bahwa novel adalah karya sastra yang mengungkapkan aspek-aspek kemanusiaan yang lebih mendalam dan disajikan dengan lebih halus (Nurgiyantoro, 2000). Adanya kenyataan tersebut maka dewasa ini novel menjadi karya sastra yang paling banyak disenangi dan diminati. Dilain fihak, sastra dianggap sebagai karya sastra yang paling dominan dalam usahanya menampilkan unsur-unsur pembangun cerita yang paling lengkap, memiliki media yang lebih luas, dan bahasa yang terdapat dalam novel cenderung bahasa yang dipergunakan sehari-hari dan umum dipergunakan oleh kelompok masyarakat dan mudah untuk dimengerti.

Novel Pasung Jiwa merupakan novel yang di dalamnya syarat akan masalah-masalah sosial dan sejatinya ada dan hidup serta berkembang dalam masyarakat umum. Cerita yang disuguhkan terkait dengan Sasana atau sasa yang 
terbelenggu atau terpasung dalam tubuh laki-laki yang memiliki kecenderungan dan ketertarikan berpakaian perempuan dan juga lagu-lagu dangdut yang akhirnya menggiringnya mendapat banyak sekali masalah baik di keluarga maupun masyarakat sosial. Jaka atau Cak Jek yang tidak kalah memberikan permasalahan dalam setiap ceritanya. Dimulai dari kehidupan sebagai pengamen bersama Sasa, menjadi buruh pabrik, dan terakhir menjadi anggota dan pemimpin dari laskar yang didengung-dengungkan membela agama atau Tuhan padahal di dalamnya tersimpan kemaksiatan dan dosa yang besar pula. Gaya penceritaan oleh penulis yang sangat khas mengenai masalah-masalah sosial pada masa orde baru dan syarat akan pelik masalah yang kental, sehingga menjadi daya tarik tersendiri dalam novel ini.

Berdasarkan uraian di atas untuk dapat mengungkap kritik sosial yang terdapat dalam novel Pasung Jiwa karya Okky Madasari, peneliti menggunakan pendekatan sosiologi karya sastra untuk menganalisisnya. Sastra merupakan refleksi dari masyarakat (Solihat, 2017). Dalam hal ini Swingewood menyampaikan hubungannya dengan sosiologi karya sastra bahwa pengarang besar tidak hanya sekedar menggambarkan keadaan dunia sosial secara mentah, akan tetapi sastra memiliki beban lebih yakni mengemban tugas yang mendesak, yakni berusaha memainkan dan menghidupkan tokoh-tokoh ciptaannya dalam satu situasi rekaan untuk mengungkapkan nilai dan makna dalam kehidupan sosial secara hidup. Peneliti menggunakan sosiologi sastra, dengan berupaya melihat isi dari karya sastra, tujuan karya sastra, serta hal-hal lain yang tersirat dalam karya sastra itu sendiri dan yang berkaitan dengan masalah sosial.

Penelitian ini memiliki perbedaan dan persamaan dengan penelitian lain. Pada penelitian terdahulu baik dari penelitian Zaenudin \& Mulyono (2018), Yulianto (2017) maupun Suhardi (2020) memiliki persamaan, yaitu meneliti kritik sosial dalam karya sastra. Akan tetapi memiliki perbedaan pula dalam fokus kritik sosial yang ditemukan dan objek kajian yang dipakai. Berangkat dari pemikiran inilah, penelitian ini dilakukan sebagai upaya untuk mengangkat kritik-kritik sosial yang terdapat dalam novel sebagai salah satu bentuk kebermaknaan karya sastra khususnya novel Pasung Jiwa karya Okky Madasari. Berdasarkan latar belakang tersebut, penelitian ini bertujuan untuk mendeskripsikan dan menjelaskan kritik-kritik sosial yang terdapat dalam novel Pasung Jiwa karya Okky Madasari.

\section{METODE}

Penelitian ini adalah penelitian kepustakaan (library research), penelitian ini melakukan kajian atau studi lewat bacaan-bacaan dan berbagai referensi yang terkai dan relevan dengan tujuan dari penelitian. Penelitian ini bersifat kualitatif dengan objek kajian berupa novel yang berjudul Pasung Jiwa karya Okky Madasari. Penerapan pendekatan sosiologi karya sastra dalam penelitian ini adalah untuk menelaah hal-hal yang terkait dengan realitas sosial yang terjadi di dalam kehidupan masyarakat khususnya masyarakat yang dikisahkan dalam karya sastra. Fokus penelitian ini adalah untuk menelaah kritik sosial yang dikisahkan oleh pengarang atau sastrawa melalui para tokoh yang terdapat dalam novel Pasung Jiwa karya Okky Madasari.

Penelitian ini dilaksanakan mulai bulan November 2019 hingga Februari 2020 meskipun tidak terikat tempat dan waktu secara khusus serta kegiatan penelitian bersifat fleksibel sesuai dengan karakteristik penelitian kualitatif. 
Metode yang dipergunakan adalah deskriptif kualitatif. Data-data yang dikumpulkan oleh peneliti berupa kosakata, kalimat, dan bias juga berupa gambar yang mempunyai arti (Sutopo, 2002; Imam, 2017). Metodologi kualitatif sebagai prosedur penelitian yang menghasilkan data deskriptif berupa kata-kata tertulis atau lisan atau dari bentuk tindakan kebijakan (Subandi, 2011). Metode ini dilaksanakan dengan berusaha menyajikan data berdasarkan realita secara lebih objektif sesuai data-data yang ditemukan dan terdapat dalam novel Pasung Jiwa karya Okky Madasari, kemudian disusul dengan analisis data.

Data dalam penelitian ini adalah teks novel Pasung Jiwa karya Okky Madasari, yang berfokus pada kritik sosial. Sumber data penelitian diambil dari novel Pasung Jiwa karya Okky Madasari yang diterbitkan pada tahun 2013. Terdapat enam tema dan beberapa sub tema di setiap bagian-bagian tema. Keenam tema tersebut adalah "Sasana", "Jaka Wani", "Sasa", "Jaka Baru", "Sang Bintang", dan "Suara Jiwa". Proses analisis data dalam penelitian ini dengan beberapa langkah, yakni mulai dari reduksi data, penyajian data, dan penarikan kesimpulan.

Pada penelitian jenis kualitatif ini, validitas lebih merupakan tujuan, bukan berupa hasil, bukan sesuatu yang dapat dibuktikan atau biasa-biasa saja (Bachri, 2010). Teknik validitas guna memastikan bahwa data sudah benar dengan menggunakan teknik trianggulasi data. Teknik trianggulasi data atau sumber berarti membandingkan dan mengecek balik derajat kepercayaan atau keabsahan suatu informasi dari narasumber satu dengan lainnya dan yang diperoleh melalui catatan atau arsip serta dokumen yang memuat catatan yang berkaitan dengan data yang dimaksudkan peneliti (Sutopo, 2002).

Teknik pengumpulan data dalam penelitian ini menggunakan Content analysis atau analisis isi. Teknik ini dimulai dengan menemukan data, mengklasifikannya, dan prediksi/analisis data. Langkah-langkah yang dilakukan dengan teknik ini meliputi: 1) membaca objek kajian secara berulang-ulang dan keseluruhan maupun sebagian novel Pasung jiwa Karya Okky Madasari, 2) mengumpulkan data dan mengklasifikasi data serta mempelajari beberapa teori yang terkai dan relevan dengan tema penelitian, dan 3) mencatat dan dilanjutkan dengan menganalisis semua data berupa kutipan penting yang sesuai dengan permasalahan yang dikaji atau diteliti.

Teknik analisis data dalam penelitian ini adalah analisis model interaktif (Interactive Model Analysis). Proses analisis data penelitian ini dimulai dengan: 1) reduksi data. Proses ini dilaksanakan dengan merangkum, memilih hal-hal yang pokok, memfokuskan pada hal-hal yang lebih penting yakni masalah sosial atau kritik sosial dalam novel; 2) penyajian data. Proses ini dilaksanakan dengan menyusun berdasarkan data yang telah digolongkan dan dianalisis serta dapat dipahami sesuai dengan tujuan penelitian. Penyajian data dalam penelitian ini berupa data yang dideskripsikan dan dijelaskan dengan kalimat logis; serta 3) penarikan simpulan. Proses penarikan simpulan atau verifikasi dilakukan dengan menyimpulkan data yang telah ditemukan dengan bukti-bukti yang valid dan konsisten dari sumber dan data penelitian terdahulu yang mendukung sesuai dengan rumusan masalah yang dirumuskan sejak awal.

\section{HASIL DAN PEMBAHASAN}

Pada bab ini disajikan hasil penelitian dan pembahasan tentang kritik sosial dalam novel Pasung Jiwa karya Okky Madasari yang akan membahas enam kritik 
sosial yang ditemukan penulis, diantaranya: 1) kritik sosial pada kungkungan orang tua atau keluarga, 2) kritik sosial terhadap kesewenangan kepada waria atau transgender, 3) kritik sosial terhadap kehidupan nestapa buruh pabrik, 4) kritik sosial terhadap kehidupan pekerja seks komersial atau PSK, 5) kritik sosial terhadap pihak yang berkuasa dan kesewenangan pemerintah, dan 6) kritik sosial terhadap adanya lascar atau pasukan pembela agama.

\section{Literasi Kritik Sosial dalam Novel Pasung Jiwa Karya Okky Madasari}

Novel Pasung Jiwa karya Okky Madasari merupakan novel yang di dalamnya syarat dengan kritik sosial. Novel ini merupakan bentuk dari salah satu kenyataan sosial yang ada secara tidak sadar maupun sadar kita mengetahuinya. Setting pada novel ini diceritakan oleh penulis terjadi pada masa Orde Baru. Kritik sosial dalam novel ini merupakan sindiran, tanggapan, atau bahkan luapan hati yang ditujukan pada suatu hak yang ada dan terjadi dalam masyarakat dimana terdapat sebuah konfrontasi dengan realitas berupa kepincangan atau kebobrokan.

Kritik sosial dapat diluapkan oleh siapapun itu yang berani dan mau dengan jalan apapun, secara langsung maupun tidak langsung. Kritik sosial dapat diluapkan oleh seseorang melalui media ataupun karya sastra. Kritik sosial yang berusaha diluapkan melalui karya sastra telah banyak dilakukan contohnya oleh Wiji Tukul. Kritik sosial yang ditumpahkan melalui karya sastra merupakan cara yang ampuh untuk menyampaikan aspirasinya mengenai ketimpangan sosial yang ada, karena sastra berbicara ketika media tidak sanggup lagi berbicara. Kritik sosial yang terdapat dalam novel Pasung Jiwa karya Okky Madasari antara lain.

\section{Kritik Pada Kungkungan Orang Tua/Keluarga}

Pada novel Pasung Jiwa terdapat cerita yang bertujuan sebagai kritik sosial terhadap kungkungan atau ambisi orang tua Sasana/Sasa kepada Sasana/Sasa. Kungkungan dan ambisi tersebut adalah selalu mengharapkan dan menggiring Sasana sebagai anak yang gemar, pandai, dan cerdas dalam memainkan piano dan juga cerdas dan selalu terdepan dalam akademik atau dalam sekolahnya. Kritik sosial terhadap kungkungan orang tua kepada Sasana juga digambarkan oleh penyair dalam setiap pilihan hidup Sasana yang selalu ditentukan oleh orang tuanya. Tidak terkecuali dengan pilihan tempat Sasana harus sekolah. Berikut penggalan kutipannya:

Ketika aku sudah tidak bayi lagi dan memasuki masa kanak-kanan, orang tuaku mendatangkan seorang guru piano untuk menjaraiku. (Pasung Jiwa: 14)

Apa yang harus aku lakukan? Tak ada. Aku laki-laki kecil tak berdaya, yang hanya bisa melakukan setiap hal yang orang tuaku tunjukkan. Aku terus memainkan piano itu. (Pasung Jiwa: 14)

Aku tak bisa membantah ketika lulus SMP dimsaukkan ke SMA khusus lakilaki. Sebuah SMA yang di kelola yayasan Katolik. Mereka berdua yang memilihkan untukku, tanpa pernah bertanya aku ingin sekolah di mana. (Pasung Jiwa: 30)

Kutipan di atas menegaskan bahwa terdapatnya disorganisasi keluarga antara Sasana dan orang tuanya. Sasana merasa tertekan dan tidak bisa melakukan apapun yang ia inginkan. Penulis dalam hal ini menunjukkan bahwa diri Sasana/sasa terkungkung dalam ego dan ambisi orang tuanya yang menginginkan anaknya pandai dalam akademik ataupun kungkungan dalam segala pilihan hidup. Bentuk disorganisasi keluarga juga tampak pada penelitian Hidayah (2018) bahwa 
sebuah perpecahan yang terjadi dalam keluarga sebagai suatu unit atau kesatuan karena anggota keluarga tidak berhasil dalam memenuhi kewajiban yang sesuai dengan peran masing-masing atau peran sosialnya.

Pada kutipan di atas, orang tua sasana beranggapan sebagai sebuah tindakan kebijaksanaan yang mereka ambil dan jalan terbaik bagi anaknya tanpa harus menanyakan dan berdiskusi terlebih dahulu mengenai keinginan Sasana. Pada kutipan tersebut menekan, selalu berpikir kebaikan, tetapi terkadang tidak menyadari bagaimana dan apa yang diinginkan oleh anak tersebut. Hal itu merupakan salah satu cara membunuh karakter anak. Hal ini senada dengan hasil temuan Ariani \& Qur'ani (2018) yang menyatakan bahwa bentuk disorganisasi dalam keluarga tersebut tentu memiliki dampak yang cukup besar pada seluruh anggota keluarga, terutama dampak terhadap anak. Adanya sebuah pertengkaran bahkan sampai berujung pada hal yang disebut perceraian akan menyebabkan keadaan mental atau psikologi dan tumbuh kembang seorang anak terganggu.

\section{Kritik Terhadap Kesewenangan kepada Waria atau Transgender}

Anggapan masyarakat dan sebutan bagi waria pun sangatlah tidak pantas. Perlakuan kepada waria pun sering sebelah mata dan dianggap bukan manusia. Waria dengan segala masalah, hal-hal yang melekat dan gaya hidupnya yang kompleks sering menjadi hal yang dimasalahkan bagi sebagian besar masyarakat dan tidak jarang dibicarakan sekaligus bersifat kontroversial (Novitasari, 2018). Posisi waria ditolak. Bahkan sampai pada tahap tidak diakui keberadaan dan eksistensi mereka. Pada umumnya dengan berbagai macam alasan dan argumentasi, baik yang cenderung bersifat normatif, psikologis, agama. Kaum wariapun tidak diakui keberadaannya oleh sebagian masyarakat. Oleh karenanya, kesewenangan dapat dilihat dalam kutipan di bawah ini.

Pintu dibuka. Tiga orang masuk ruangan.

Ini to orangnya...Suit...suit...seksi yo, rek! (Pasung Jiwa: 2013)

Enaknya kita apain bencong ini?" tanya si Komandan.

Kita pakai saja dulu, Ndan. Biasanya juga dipakai orang," jawab yang lainnya. Mereka lalu terbahak bersama. (Pasung Jiwa: 2013)

"Dasar bencong! Tidak bisa ngomong yang benar. Memang harus dibikin agar mulutnya itu ngomong apa adanya".

Penisnya dimasukkan ke mulutku. Sambil tangannya memegang kepalaku dan menggerak-gerakannya. Mereka semua tertawa. Aku meronta, berteriak tanpa bersuara. Sakit rasanya. Sakit yang begitu dalam. Terhina, tak dihargai sebagai manusia. Ada cairan terasa di mulutku. Aku masih tak bisa mengangkat kepala. Orang itu memaksaku menelannya. (Pasung Jiwa: 2013)

Kutipan di atas mengungkap kenyataan dan kritik akan keadaan serta perlakuan yang diterima waria dari banyak orang atau beberapa orang. Banyak yang menganggap waria hanya sebagai pemuas nafsu dan bekerja di cebongan atau tempat-tempat prostitusi. Dunia prostitusi atau lebih dikenal dengan dunia pelacuran, bagi kaum waria atau transgender sudah menjadi bentuk budaya tersendiri bagi kehidupan kaum waria itu sendiri (Puspitosari \& Sugeng, 2005). Digambarkan pelik konflik oleh penulis tersebut sebagai kritik sosial akan kesewenangan perlakuan yang ditujukan kepada kaum waria sebagai kaum yang terpinggirkan dan ditolak oleh masyarakat. Perlakuan tidak manusiawi yang 
digambarkan oleh Okky dalam novelnya terhadap waria juga terdapat dalam kutipan berikut:

Kini dia menarik tubuhku, lalu dengan kasar menarik celana dalamku sampai putus dan lepas begitu saja. Ia dorong tubuhku mengahdap ke dinding. Lalu ... aaaaaargh! Sakit, sakit. Sakit di hati. Sakit di tubuh. Mereka melakukannya bergiliran. Aku benar-benar sudah merasa bukan lagi manusia. (Pasung Jiwa: 2013)

Kutipan cerita tersebut menggambarkan bagaimana oknum yang seharusnya melindungi masyarakat malah menjadi oknum yang sangat brtanggung jawab atas penderitaan masyarakat. Ketika ada seorang waria yang dianggap sebagai PSK (pekerja seks komersial) dan melakukan kesalahan maka mereka dengan tanpa berdosa dan tanpa bersalah memperlakukan waria Sasa layaknya binatang. Bagaimanapun waria Sasa berkata jujur mereka hanya memukul dan melecehkan waria Sasa tersebut dengan membabi buta.

\section{Kritik Terhadap Kejahatan terhadap Buruh Pabrik}

Pada novel Pasung Jiwa ini, juga terdapat kesewenang-wenangan terhadap kaum buruh pabrik dan tidak mendapat perlindungan dari oknum yang berkewajiban yakni pemerintah dan atasan, akan tetapi malah mendapat berbagai macam pelecehan dan juga penindasan. Cerita yang disuguhkan disini, merupakan kritik terhadap adanya kejahatan pada kaum-kaum yang tidak memiliki kuasa. Hal serupa juga terdapat pada penelitian Suhardi (2020) juga ditemukan masalah kejahatan yang berusaha dikritisi yaitu dimulai dari penipuan, pembunuhan, ketidakadilan, perampokkan bahkan sampai pada tindak penyiksaan. Kutipan dibawah ini semakin mempertegas kritik sosial yang digambarkan oleh Okky Madasari.

Hai, kalian para mesin, kalian di sini hanya untuk bekerja. Walaupun Cuma satu kata yang kalian ucapkan, itu artinya mengurangi waktu bekerja. (Pasung Jiwa: 163)

Kutipan di atas menunjukkan hidup hanya mburuh dan terkekang oleh pekerjaan yang ekstra ketat. Istilahnya, hilang waktu bekerja, sekecil apapun kesalahan adalah kerugian bagi pabrik dan dirinya sendiri. Semua dihitung dengan uang tanpa melihat sisi kemanusiaan seseorang. Terlihat dalam penggalan di atas bahwa nilai-nilai kemanusiaan yang mulai memudar dengan merendahkan manusia lain. Kritik sosial terkait dengan nilai kemanusiaan juga muncul pada penelitian Zaenudin (2018) yang menjelaskan nilai kemanusiaan yang terdapat dalam naskah drama tersebut mengenai harkat dan martabat manusia dalam masyarakat.

Mandor bejat! Pabrik Bejaaat! Seenaknya mecat orang setelah disedot habis-habisan.

Saya bongkar semuanya sekarang! Biar semua orang di sini tahu!

Kini perempuan itu lari ke tengah ruangan, berdiri di meja terdepan.

Mandor itu... Mandor itu sudah memperkosa saya!

Perempuan itu berbicara sambil menuding si Mandor. (Pasung Jiwa: 2013). 
Kutipan di atas digambarkan oleh penulis sebagai kritik akan pelecehan dan sikap tidak manusiawi yang marak terjadi pada buruh pabrik wanita. Tidak jarang buruh pabrik wanita dijadikan pemuas nafsu bejat dari atasan dan mandor atau orang yang memiliki kuasa. Tidak jarang pula hanya dengan memecat mereka lalu urusan dianggap selesai dan beres. Pada kutipan tersebut Okky Madasari berusaha menguak tabir kelam yang menyelimuti kehidupan buruh pabrik khususnya buruh wanita yang selalu dilecehkan oleh oknum-oknum tidak bertanggung jawab. Upah rendah dan ketakutan akan menjadi pengangguran serta tidak dapat mencari makan adalah alasan mereka diam diperlakukan tidak manusiawi seperti itu. Dan para oknum yang tidak bertanggung jawabpun menjadikan pemecatan sebagai ancaman kepada mereka yang diperkosa. Kutipan dibawah ini mempertegasnya:

"Kita kan sudah pernah melawan. Tetap saja kita dipecat. Tetap saja tidak ada yang peduli," Kata Sarti.

...

Aku yakin pasti banyak yang diperkosa seperti kalian. Tapi semuanya tidak ada yang berani bicara."

"Karena mereka tidak bunting!” Kata Sasti.

"Betul, kalau tidak bunting pasti kami juga pilih diam," sambung Kalina. (Pasung Jiwa: 2013)

Tidak berhenti di situ saja. Kesewenang-wenangan terhadap buruh pabrik juga tergambar jelas dalam cerita novel ini terkait dengan penghilangan nyawa buruh yang hendak meminta naik upah bagi mereka buruh wanita.

Seminggu sebelum hilamg, Marsini ikut minta naik upah, begitu cerita yang didapat Cak Man dari teman-teman Marsini. Lima orang termasuk Marsini, menghadap mandor agar menyampaikan permintaan itu ke atasan. Karena tak digubris mereka nekat menghadap bagian personalia. Lima orang ini berani melakaukan hal itu, karena kenaikan upah yang mereka minta hanya mengikuti peraturan baru pemerintah yang sah. Pertemuan dengan kepala personalia tetap tak membuahkan hasil. Lima orang ini membagikan selebaran ke semua buruh. Mengajak mogok sampai ada kenaikan upah. Sehari sebelum tanggal pelaksanaan mogok kerja, lima orang itu hilang. Termasuk Marsini. (Pasung Jiwa: 2013)

Upah rendah yang diterima buruh wanita tersebut, membuka tabir bagaimana realita sosial di masyarakat memang begitu adanya, dan banyak dari mereka yang berani menggugat seterusnya tidak diketahui dimana mereka, dan bagaimana kehidupan mereka setelahnya. Seharusnya kaum buruh dilindungi oleh pemerintah karena mereka juga warga dari Negara juga. Okky Madasari dengan kejeliannya mengungkap tabir kelam akan kehidupan buruh yang sejatinya hanya menjadi buruh yang tidak dapat menggugat apa pun sekalipun meminta hak mereka sendiri. Di sinilah pemerintah harusnya bertindak sesuai dengan porsinya dan melindungi mereka yang berhak dilindungi bukan hanya mencari untung dari mereka tanpa memikirkan kemanusiaan (Sefia \& Septiaji, 2018).

\section{Kritik Terhadap Kehidupan Pekerja Seks Komersial (PSK)}

Pada novel Pasung Jiwa ini juga terdapat kritik sosial yang terjadi pada kehidupan malam para Pekerja Seks Komersial (PSK) atau pelacuran. Pelacuran dapat dimaknai dengan suatu pekerjaan yang lebih bersifat menyerahkan diri secara fisik kepada umum untuk melakukan perbuatan-perbuatan dalam ranah 
seksual dengan mendapatkan upah atau bayaran dari jasa mereka (Hidayah, 2018). Okky Madasari menggambarkan ceritanya dengan sangat baik dengan menautkannya dengan kehidupan buruh pabrik Jaka Wani. Dari keterpautan tersebut dapat diungkap bagaimana kehidupan PSK yang harus bekerja dibawah kaki germonya dan mendapat jatah yang tidak sesuai dengan kerjaya. Berikut kutipannya:

Ia tertawa panjang. Wajahnya tampak puas. Entah puas karena permainanku atau puas karena uangku.

"Tidak buat saya semua, Mas. Bosnya kan mesti juga disetori,” katanya."

"Berapa yang mesti disetor?" tanyaku.

Mukanya kini tampak musam. "Tiap terima tamu satu jam saya Cuma dapat lima ribu, Mas."

"Hah?" Aku heran. Tarifnya lima belas ribu per jam. Tapi ternyata yang jadi bagiannya cuma lima ribu. Sisanya untuk si bos. "Kok bisa kamu mau setor sebanyak itu?"

"Ya mau bagaimana lagi? Mereka yang punya tempat. Mereka yang bisa datangin tamu." (Pasung Jiwa: 2013)

Sejalan dengan itu, hak seorang PSK pada novel ini juga digambarkan oleh Okky Madasari dengan sangat mengena. Diksi yang dipakai juga cukup berani dan menggambarkan realita sosial PSK. Perhatikan kutipan berikut.

"Bajingan semua mereka!" kata Elis ketika aku sudah berjalan di sampingnya. "Disuruh pakai kondom saja tidak mau. Ya sori saja, saya tidak sudi!”

"Saya ini kerja, Mas. Cari duit. Kalau saya nanti saya hamil, yang tanggung jawab siapa? Kalau nanti kena penyakit, bagaimana?"

"Sudah banyak kejadian, Mas. Ada yang hamil, disuruh pergi. Ada yang kena penyakit, disuruh pergi. Kalau saya sampai begitu, saya dapat duit dari mana? Mau ngirimi anak bagaimana?" (Pasung Jiwa: 2013)

Penggambaran tokoh dan cerita pada kutipan di atas, menegaskan bahwa kehidupan PSK tidak semudah yang dibayangkan seseorang. Kutipan tersebut digambarkan oleh penulis lekat dengan realita sosial dan sebagai kritik sosial akan hak PSK serta kewajiban bagi mereka yang membeli tubuh PSK. Pada kasus ini, Okky Madasari berusaha mengungkap sedikit cerita kelam dibalik keglamoran kehidupan PSK dalam mengundang tamunya. Kutipan tersebut juga sebagai kritik sosial akan keberadaan mereka yang masih mempertimbangkan hal-hal lain diluar kenikmatan duniawi dan melayani pembeli saja.

\section{Kritik Terhadap Pihak yang Berkuasa dan kesewenagan Pemerintah}

Pada novel Pasung Jiwa terdapat banyak cerita yang memuat kesewenangwenangan kekuasaan dan pemerintahan pada masa Orde Baru. Orde Baru dengan semua sokongan baik dari bala-tentara dan juga kaum terpelajar atau cendekiawan mengontrol bahasa dan juga pengetahuan. Oleh karenanya, pihak ataupun individu yang mencoba bergerak atau melakukan kegiatan yang tidak sesuai dan di luar kontrol akan segera berurusan dengan alat pengontrol negara yaitu polisi dan tentara.

Di samping itu, solusi super cepat juga telah digunakan oleh pemerintahan Orde Baru. Solusi tersebut juga dianggap sebagai solusi super-efektif, yakni 
penculikan. Penculikan para aktivis yang berusaha pro-demokrasi dan juga orang yang kritis merupakan media pembungkam suara dan tindakan rakyat paling berhasil. Keragaman (pluralitas) berdiri sejajar dan setara sebagai power dalam proses kritik yang sehat. Kritik terhadap kesewenang-wenangan kekuasaan dan pemerintah terdapat dalam kutipan sebagai berikut:

Itu pun karena tiba-tiba Ibu ingat dan menanyakan sampai di mana proses hokum lima orang itu.

"Ada satu anak jenderal, satu anak pejabat. Kasusnya tidak bisa diproses," jawab Ayah datar.

"Hah? Anak kita disiksa seperti anjing lalu pelakunya tidak bisa diproses?" Ibu berteriak. (Pasung Jiwa: 2013)

Kutipan tersebut digambarkan oleh penulis pada saat Sasana dihajar oleh segerombolan genk yang menamakan genk mereka dengan Dark Genk. Sasana diperas untuk selalu meyetor uang kepada genk mereka dan jika tidak mau maka akan dihajar habis-habisan layaknya binatang. Orang tua Sasana melaporkan kejadian tersebut ke pihak yang berwajib tapi kasusnya tidak dapat diproses karena anggota Dark genk tersebut ada yang anak jenderal dan anak pejabat. Disinilah letak kritik sosial yang coba diangkat oleh Okky Madasari. Pengaruh kekuasaan yang tidak dapat menunjukkan mana yang benar dan mana yang salah. Kejahatan dan pelanggaran HAM tidak dapat diproses layaknya hukum yang dicanangkan di negeri ini.

"Mereka mengancam ke kantor Ayah..."

"Tapi mereka dikeluarkan dari sekolah, kan?” Tanya ibu tiba-tiba. $\cdots$

Yayasan tak berani. Mereka minta Sasana yang dipindahkan. Demi kebaikan bersama... . (Pasung Jiwa: 2013)

Kutipan di atas semakin mempertegas bagaimana pengaruh kekuasaan dapat menutup kebenaran. Semua semakin tidak sejalan dengan seharusnya dan semestinya. Mereka yang mendapat ketidakadilan dan menderita karena perlakuan dari pihak yang berkuasa hanya bisa menerima dengan perasaan sakit dan tubuh yang sakit pula. Karena kedudukan dan kekuasaan dari jenderal dan pejabat maka kedudukan Sasana sebagai korban dan perlakuan tidak manusiawi dari Dark genk tidak diproses begitu saja. Kritik sosial ini yang berusaha disuguhkan oleh Okky Madasari dalam ceritanya. Realitas sosial seperti ini hidup dan berkembang dalam masyarakat umum. Tidak ada yang berani melawan jika semua sudah diancam dan dikalahkan oleh orang yang lebih berkuasa dan mempunyai pengaruh (Sriwahyuni \& Asri, 2020). Selain yang sudah dikemukakan di atas, kesewenangan pemerintah pada masa Orde Baru juga digambarkan oleh penulis dengan penculikan, penyiksaan dan penghilangan nyawa bagi mereka yang prodemokrasi.

DOR! Bunyi tembakan menghentikan kami semua. Polisi dan Tentara sudah ada di sekeliling kami. Tak terlalu banyak bicara, senapan kini ada di sekeliling kami. Ikuti kata mereka atau peluru akan menembus kepala.

Setiap hari mereka melakukan hal yang sma. Membawaku keluar dari sel, menanyaiku sekali-dua kali, lalu sisanya mereka gunakan tubuhku untuk 
melayani mereka. Aku kehilangan harapan, sampai pada hari keempat belas, mereka membawaku keluar gedung itu. Baru aku tahu di mana sebenarnya aku berada selamaini. Kantor Koramil. (Pasung Jiwa: 2013)

Kutipan di atas menggambarkan bagaimana penyiksaan oleh tentara yang diterima Sasana karena sikapnya dan teman-temannya dengan demontrasi menghendaki Marsini si buruh pabrik di Sidoarjo dikembalikan ke keluarganya. Pemerintah dengan tentaranya tidak berusaha untuk menanggapi apa yang menjadi keluhan masyarakat dengan hilangnya Marsini, malah mereka menyiksa dan melecehkan Sasana di dalam sel tahanan. Ini merupakan kritik sosial yang berusaha dikemukakan oleh Okky Madasari dalam novelnya. Kebejatan oknum tentara yang seharusnya menjaga dan melindungi masyarakat dan Negara tetapi malah sebaliknya. Kritik di atas sejalan dengan temuan Kurniawan (2019) yang menyebutkan bahwa dalam novel grafis, represi tersebut ditunjukkan lewat jalur yang tidak jauh berbeda dengan kasus hilangnya Marsini, yakni lewat jalur kekerasan. Jalur ini ditunjukkan lewat usaha pihak penguasa yang berusaha membunuh orang-orang yang hendak membongkar misteri harta Centini.

\section{Kritik Terhadap Adanya Laskar/Pasukan Pembela Agama}

Selain banyak sekali kritik sosial yang dikemukakan di atas, dalam novel ini juga terdapat pelik cerita dan konflik mengenai laskar atau pasukan yang bertitelkan pembela agama. Pembela agama yang digambarkan oleh Okky Madasari sangatlah kompleks. Mereka yang mengaku pembela agama bahkan tidak mengerti bagaimana beragama yang baik itu. Banyak sekali cerita dan kejadian-kejadian yang disebutkan dalam cerita terkait dengan laskar pembela agama ini. Kritik sosial tersebut sebagai berikut.

Malam mini ada lima sumber maksiat yang kami beri pelajaran. Sepanjang jalan pulang, kami meneriakkan kata-kata kemenangan sambil mengacungkan senjata dengan tangan kanan. Tangan kiri kami memegang botol-botol minuman bersoda yang kami ambil dari kafe yang kami hancurkan. Minuman itu halal maka kami bisa meminumnya. (Pasung Jiwa: 2013)

Kutipan tersebut memberi gambaran kepada masyarakat mengenai laskar yang mendengungkan bahwa mereka membela agama. Namun demikian, agama tidak menyuruh untuk menindas orang lain dan mengambil barang-barang. Agama merupakan alat pengesahan yang dianggap paling efektif dan berdasar. Banyak insan yang mengaku beragama kemudian dengan berlagak polos dan berlindung di balik jubah agamanya untuk usaha memperjuangkan kepentingan tertentu, tidak terkecuali kepentingan politik (Kurniawan, 2011). Pada penelitian Kurniawan menunjukkan bahwa Remy Sylado mengutarakan hasil kritiknya yang membahas mengenai perilaku berlebihan umat yang mengaku beragama dalam menunjukkan simbol-simbol agamanya.

Sejalan dengan temuan Kurniawan, dalam penelitian ini ditemukan perlakuan laskar pembela agama dengan menghancurkan kafe yang mereka anggap tempat maksiat dan kemudian mengambil atau mencuri botol minuman bersoda juga termasuk maksiat. Di sinilah Okky Madasari berusaha menggambarkan kritik sosial yang fenomena tersebut tidak jarang terjadi di Masyarakat. 

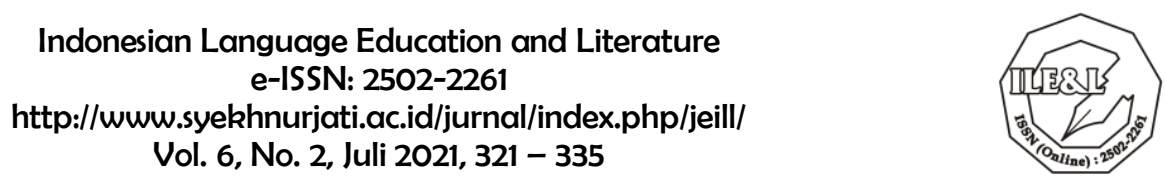

Mereka yang mengaku membela agama tapi sejatinya mereka tidak mengerti ajaran agama itu sendiri. Kutipan di bawah ini semakin mempertegas:

"Di tengah tawa, Jali membuka tas punggungnya. Ia keluarkan botol-botol dari dalamnya. Aku melongo. Sementara kawan-kawan yang lain berseru kegirangan. "Sesekali kita juga boleh berpesta,"kata Jali. (Pasung Jiwa: 2013)

Pada kutipan di atas, penulis menceritakan bahwa laskar pembela agama seusai merusak kafe yang mereka anggap tempat maksiat malah berpesta minuman keras. Kemunafikkan terjadi di sini. Kritik sosial akan kemunafikkan yang terdapat pada kelakuan laskar pembela agama di sini menjadi titik tolak pelik masalahnya. Mereka mendengungkan pembelaan terhadap agama dan merusak hal-hal yang dianggap maksiat tetapi mereka sebenarnya adalah pemaksiat juga.

Kritik sosial yang berusaha diangkat oleh penulis adalah bagaimana mereka yang menganggap dirinya pembela agama tapi bertindak seperti tidak memiliki agama. Cara yang dipergunakan adalah cara yang anarkis dan jauh dari ajaran agama. Tidak ada yang berhak menghakimi seseorang sampai sehina itu dan bahkan menghabisi nyawanya tanpa mengetahui kebenaran yang ada.

\section{SIMPULAN}

Kritik sosial dalam novel ini merupakan sindiran, tanggapan, atau bahkan luapan hati yang ditujukan pada suatu hak yang terjadi dalam masyarakat, khususnya kaum yang termarginalkan. Hal ini manakala terdapat sebuah pertentangan atau konfrontasi dengan realitas berupa ketimpangan, kepincangan atau kebobrokan. Hasil penelitian ini dapat menjadi salah satu acuan dan referensi dalam memahami kritik sosial yang disampaikan oleh Okky Madasari. Sejalan dengan itu, diharapkan pada pembaca juga dapat memperoleh pengalaman dan wawasan tentang kritik sosial dalam upaya memahami berbagai pelik masalah sosial dan sampai pada mengatasi masalah yang terjadi dalam sebuah masyarakat.

\section{DAFTAR PUSTAKA}

Ariani, M. F., \& Qur'ani, H. B. (2018). Kritik Sosial dalam Naskah Drama Kampong Kardus Karya Gepeng Nugroho. Jurnal Pena Indonesia (JPI), $4(2), 115-135$.

Artika, I. W. (2015). Teori dalam Pengajaran Sastra. PRASI, 10(19), 18-27.

Bachri, B. S. (2010). Meyakinkan Validitas Data Melalui Trianggulasi Pada Penelitian Kualitatif. Jurnal Teknologi Pendidikan, 10(1), 46-62.

Brahmana, P. S. (2008). Sastra Sebagai Sebuah Disiplin Ilmu. Logat Jurnal Ilmiah Bahasa dan Sastra, IV(2), 116-121.

Hidayah, S. T. (2018). Perilaku Sosial Pekerja Seks Komersial (PSK) di Dunia Pelacuran. Jurnal Ijtimaiya, 2(1), 111-134.

Imam, A. (2017). Kritik Sosial dalam Novel O Karya Eka Kurniawan: Kajian Sosiologi Sastra. Jurnal HUMANIS, 9(2), 127-134.

Kosasih. (2012). Dasar-Dasar Keterampilan Bersastra. Bandung: Yrama Widya

Kurniawan, M. A. (2011). Kritik Sosial dalam Novel Menunggu Matahari Melbourne Karya Remy Sylado: Tinjauan Sosiologi Sastra. Bahastra, 26(1), $1-17$. 
Kurniawan, M. A. (2019). Kritik Sosial dalam Novel Grafis Sukab Intel Melayu Karya Seno Gumira Ajidarma. Lingua Rima, 8(1), 87-96.

Krisdayanti, W. O., Udu, S., \& Balawa, L. O. (2020). Kritik Sosial dalam Novel Lintasan Menikung Karya Arsyad Salam. Basastra, 5(3), 334-345.

Madasari, O. (2013). Pasung Jiwa. Jakarta: PT. Gramedia Pustaka Utama.

Melati, I. K. (2019). Kritik Sosial dalam Novel Orang Orang Biasa Karya Andrea Hirata. Senasbasa, 3(2), 474-483.

Mulyaningsih, I. (2015). Kajian Feminis Pada Novel "Ronggeng Dukuh Paruk" dan "Perempuan Berkalung Surban". Indonesian Language Education And Literature (ILEAL), 1(1), 107-119. DOI: 10.24235/ileal.v1i1.75.

Novitasari, L. (2018). Penyimpangan Perilaku Seks Waria dalam Novel Taman Api Karya Yonathan Rahardjo. Deiksis, 10(2), 125-133.

Nurgiyantoro, B. (2000). Teori Pengkajian Fiksi. Yogyakarta: Gajah Mada.

Pratiwi, Y. I., Harun, M., \& Herman. (2018). Kritik Sosial dalam Novel Tanah Surga Merah Karya Arafat Nur. JIM PBSI, 3(3), 281-293.

Puspitosari, H. P., \& Sugeng. (2005). Waria dan Tekanan Sosial. Malang: UMM Press.

Sadewa, I. K. (2012). Sajak "Nyanyian Angsa" Karya WS. Rendra: Analisis Antropologi Sastra. Jurnal Pustaka, XII(1), 65-82.

Sariban. (2015). Penelitian Sastra Teori dan Penerapan. Surabaya: Lentera Cendikia.

Satrio, B. S., Doyin, M., \& Suseno. (2014). Kritik Sosial dan Hegemoni Kumpulan Cerpen Emak Ingin Naik Haji Karya Asma Nadia. Jurnal Sastra Indonesia, 3(1), 1-9.

Sefia, A. Y., \& Septiaji, A. (2018). Hujan Bulan Juni Karya Sapardi Djoko Damono: Kritik Sastra Mimetik. Diglosia, 2(1), 1-13.

Solihat, I. (2017). Konflik, Kritik Sosial, dan Pesan Moral dalam Naskah Drama Karya Nano Riantiarno (Kajian Sosiologi Sastra). Jurnal Membaca, 2(1), 29-36.

Sriwahyuni, I., \& Asri, Y. (2020). Kritik Sosial dalam Novel Nayla Karya Djenar Maesa Ayu. Jurnal Pendidikan Bahasa dan Sastra Indonesia, 9(1), 90-96.

Subandi. (2011). Deskripsi Kualitatif Sebagai Satu Metode dalam Penelitian Pertunjukan. Harmonia, 11(2), 173-179.

Sugiwardana, R. (2014). Pemaknaan Realitas serta Bentuk Kritik Sosial dalam Lirik Lagu Slank. Skriptorium, 2(2), 86-96.

Suhardi, O. E. (2020). Potret Kritik Sosial dalam Cerpen "Malam Laksmita" Karya S Prasetyo Utomo. Jurnal Bahasa, Sastra Indonesia, dan Pengajarannya, 3(2), 56-65.

Sutejo \& Kasnadi. (2010). Kajian Prosa, Kiat Menyisir Dunia Prosa. PonorogoJogjakarta: P2MP SPECTRUM-Pustaka Felicha.

Sutopo. (2002). Metodologi Penelitian Kualitatif: Dasar Teori dan Penerapannya dalam Penelitian. Surakarta: Sebelas Maret University Press.

Wahyudi, T. (2013). Sosiologi Sastra Alan Swingewood Sebuah Teori. Jurnal Poetika, 1(1), 55-61.

Wellek, R., \& Warre, A. (2014). Teori Kesusastraan. Jakarta: PT Gramedia.

Yulianto, A. (2017). Kritik Sosial dalam Dua Cerita Pendek Karya Pengarang Kalimantan Selatan. Jurnal Bébasan, 4(2), 121-132. 
Zaenudin, Z., \& Mulyono, M. (2018). Kritik Sosial dalam Naskah Drama Obrog Owok-Owok Ebreg Ewek-Ewek Karya Danarto: Tinjauan Sosiologi Sastra. Jurnal Sastra Indonesia, 7(3), 165-172. 